\title{
Compensation and the Damages Directive
}

\author{
Sebastian Peyer ${ }^{*}$
}

\section{Abstract:}

The EU Damages Directive came into force in December 2014. One of its objectives is to ensure that anyone who has suffered harm caused by infringements of competition law can effectively exercise the right to claim full compensation in the courts of the EU Member States. This paper looks closely at the Directive's compensation goal and the key arrangements that are to encourage victims to seek redress in the national courts. The paper uses a simple framework to demonstrate that the legal measures in the Damages Directive are unlikely to foster compensation because they fail to create incentives for harmed individuals to seek redress. If Member States seek to encourage full compensation, they should devise a framework for private antitrust actions that goes beyond the Directive's remit by, for example, allowing class actions.

Key words: Private antitrust enforcement; competition law; damages action; Damages Directive; Directive 2014/104/EU; EU competition law

JEL classification: K41, K42

\footnotetext{
* Lecturer in Law, University of East Anglia. The author can be contacted at s.peyer@uea.ac.uk. I would like to thank Cosmo Graham, Morten Hviid, Andreas Stephan, Mel Marquis, two anonymous referees and the members of BECCLE and CCP for their valuable comments and feedback on earlier versions of this paper.
} 


\section{A. Introduction}

For many years the European Commission has advocated the use of tort claims to enforce Articles 101 and 102 TFEU and the national equivalents. It initiated a discussion about the state and role of private antitrust litigation in the EU Member States and how to facilitate damages claims at the turn of the millennium. After more than a decade of consultations, reports and discussion, the stakeholders agreed on certain measures to regulate and harmonise antitrust damages actions. ${ }^{1}$ These measures came into force with the Damages Directive in December $2014 .^{2}$

The Directive pursues two main objectives. The first is to safeguard the effective private enforcement of EU competition law by harmonizing the framework for compensation claims across the Member States. The rules in the Directive endeavour to ensure that "anyone who has suffered harm caused by an infringement of competition law [...] can effectively exercise the right to claim full compensation". ${ }^{3}$ The Directive obliges Member States to introduce certain measures to encourage individuals to seek compensation for harm caused by breaches of competition law. The second goal of the Directive is to coordinate public and private enforcement - a circumlocution for limits that are imposed on private damages actions to protect public law enforcement. Private actions that follow the announcement of a public investigation by a competition authority can interfere with that investigation. If, for example, a potential claimant seeks access to evidence that is in the hands of the competition authority, it may reduce the willingness of firms to cooperate with the competition authority if the cooperation would subsequently expose the firm to (greater) civil liability in the national courts. ${ }^{4}$ The coordination goal places limits on the goal of effective compensation.

\footnotetext{
${ }^{1}$ For a list of key documents see http://ec.europa.eu/competition/antitrust/actionsdamages/documents.html.

2 Directive 2014/104/EU of the European Parliament and of the Council on certain rules governing actions for damages under national law for infringements of the competition law provisions of the Member States and of the European Union [2014] OJ L 349/1 (hereinafter "Damages Directive" or "Directive").

${ }^{3}$ Article 1(1).

4 Recital 25. Buccirossi et al. argue that damages actions do not reduce the attractiveness of leniency programmes. Paolo Buccirossi, Marvao, Catarina Moura Pinto and Giancarlo Spagnolo, 'Leniency and Damages' (2015) Centre for Economic Policy Research Discussion Paper Series.
} 
In this paper, I am scrutinising the compensation goal of the Directive and whether the Directive's legal measures will make it more likely that victims seek redress from the infringer. My analysis will focus on the compensation goal because it epitomises the damages actions reform and it has been stressed by all Commissioners involved in the making of the Directive. For example, Margrethe Vestager, referring to the Damages Directive, announced that "[...] it will be easier for European citizens and companies to receive effective compensation for harm caused by antitrust violations". ${ }^{5}$ For my analysis, I propose a simple framework to identify the factors that are likely to incentivise legal action and, thus, the factors that are likely to encourage victims to seek redress. I will also identify those aspects that are more likely to discourage victims from asking for compensation. Based on this framework, I shall look into the potential effects of Damages Directive, asking whether it is likely to encourage individuals to seek compensation. I argue that the Damages Directive does not encourage more claims. When the Directive provides incentives to commence legal action, they are either outweighed by the limitations that are placed on private claims or by the costs associated with a more elaborate system of compensation claims. If more compensation claims are desired, the Member States ought to introduce rules on private antitrust enforcement that go beyond the narrow framework of the Damages Directive.

This study has some caveats. First of all, I will work with a number of contentious assumptions that underpin the Damages Directive. For the purpose of this study, I will assume that the goal of more effective compensation, i.e. more damages claims, is sound. ${ }^{6}$ । doubt that more private claims will help victims of anticompetitive conduct to obtain more effective compensation. However, I shall presume that this is true for the purpose of this paper which is to assess the rules of the Directive in the light of its compensation goal. I will also assume that the proposed measures are based on sound assumptions, in other words, that there is a lack of private damages actions and that the non-harmonised national rules discourage claimants from seeking damages. With regards to these issues I have pointed to

\footnotetext{
${ }^{5}$ Press Release of the European Commission, Antitrust: Commission welcomes Council adoption of Directive on antitrust damages actions (Brussels, 10 November 2014).

${ }^{6}$ For a critical view on 'boosting enforcement', see Donald I Baker, 'Revisiting History - What Have We Learned About Private Antitrust Enforcement that We Would Recommend to Others' (2004) 16 Loyola Consumer Law Review 379-408.
} 
the lack of empirical evidence elsewhere and I will not reiterate my criticism here. ${ }^{7}$ Finally, there are limitations as to explanatory power of my observations. I will look at the potential effects of isolated rules but this is not a precise science. There are a number of factors that are not being accounted for in the stylised framework I am going to use. Furthermore, the Member States have two years until December 2016 to implement the Directive into national law. ${ }^{8}$ The Damages Directive creates room for interpretation and National legislators may read the rules of the Damages differently. Consequently, national rules may diverge and so may the incentives provided for in the respective jurisdiction.

In the next section B, I will briefly outline the background and the content of the Directive to illustrate the limitations, goals and scope thereof. Part $C$ develops a simple framework to determine the factors that incentivise potential claimants to bring legal actions. This framework is then applied to the rules of the Directive in section D. Part E concludes.

\section{B. The Damages Directive}

\section{Background and objectives}

In this part, I will briefly retrace the formation of the Directive, its goals and the rules that are to be implemented in the Member States. The Damages Directive has been in the making for more than a decade under three different commissioners. ${ }^{9}$ It implements two decisions of the Court of Justice of the European Union (CJEU) that clarified that there is a right to compensation for the breach of EU competition law. ${ }^{10}$

\footnotetext{
7 Sebastian Peyer, 'Private Antitrust Litigation in Germany from 2005 to 2007: Empirical Evidence' (2012) 8 Journal of Competition Law and Economics 331-359.

${ }^{8}$ Article 21(1).

${ }^{9}$ Mario Monti (1999-2004), Neelie Kroes (2004-2009), Joaquín Almunia (2010-2014).

${ }^{10}$ Case C-453/99 Courage Ltd v Bernard Crehan, ECLI:EU:C:2001:465 [2001] ECR I-6297; Case C-295/04 Vincenzo Manfredi v Lloyd Adriatico Assicurazioni SpA, ECLI:EU:C:2006:461 [2006] ECR I-6619.
} 
The European Commission began to explore the options for reforms by consulting interested parties on damages-related questions in the Green Paper in $2005,{ }^{11}$ followed by a consultation on the White Paper proposals in 2009. ${ }^{12}$ The Ashurst Report informed the Commission in the drafting stages of the Green Paper and provided material about the legal situation in the Member States. ${ }^{13}$ It also attempted to provide empirical evidence with regards to private damages actions for the infringement of competition law. The White Paper of 2009 was flanked by a study on the potential welfare effects of different options for reform. ${ }^{14}$ In the course of the consultations, the focus of the damages actions reform changed from compensation and deterrence in the Green Paper ${ }^{15}$ towards a more compensation-centred perspective in subsequent documents, also excluding group actions from the Damages Directive. ${ }^{16}$ The Commission consulted on the quantification of damages and published a practical guide for judges. ${ }^{17}$ The quantification guidance does not form part of the Directive. Class or group actions were considered separately and the Commission issued a recommendation on common principles rather than regulating collective redress in the Directive. ${ }^{18}$

It is crucial to understand the assumptions that underpin the reform process. Most stakeholders subscribe to the view that private antitrust enforcement in the EU Member States is underdeveloped and that claimants face considerable obstacles when pursuing

${ }^{11}$ Green Paper - Damages Actions for Breach of the EC Antitrust Rules, COM(2005) 672 final (19 December 2005).

${ }^{12}$ White Paper on Damages Actions for Breach of the EC Antitrust Rules, COM(2008) 165 final (2 April 2008).

${ }^{13}$ Waelbroeck, Denis; Slater, Donald; Even-Shoshan, Gil, Study on the Conditions for the Claims of Damages in Case of Infringement of EC Competition Rules (Brussels 2004).

${ }^{14}$ Renda, Andrea, et al, Making Antitrust Damages Actions more Effective in the EU: Welfare Impact and Potential Scenarios (Brussels 2008).

${ }^{15}$ The Green Paper also considered group actions. Green Paper (n 11), para 2.5.

${ }^{16}$ Compensation would also lead to more deterrence, see White Paper ( $\mathrm{n} 12$ ), para 1.2. The Damages Directive refers to deterrence only in the context of private enforcement potentially deterring cooperation with the competition authorities, see Damages Directive, recital 26.

${ }^{17}$ Draft Guidance Paper - Quantifying Harm in Actions for Damages Based on Breaches of Article 101 or 102 of the Treaty on the Functioning of the European Union (Brussels 2011); European Commission, Communication from the Commission on Quantifying Harm in Actions for Damages Based on Breaches of Article 101 or 102 of the Treaty on the Functioning of the European Union (C(2013) 3440) (Brussels 2013).

${ }^{18}$ Commission Staff Working Document - Public Consultation: Towards a Coherent European Approach to Collective Redress (Brussels 2011); Commission Recommendation of 11 June 2013 on common principles for injunctive and compensatory collective redress mechanisms in the Member States concerning violations of rights granted under Union Law [2013] OJ L201/60. 
antitrust damages claims in the courts. ${ }^{19}$ According to the European Commission, individuals forego compensation in the range of several billion Euros every year. ${ }^{20}$ The failure to obtain redress "[...] is largely due to various legal and procedural hurdles in the Member States' rules governing actions for antitrust damages before national courts." ${ }^{21}$ Two conclusions were drawn from these findings. First, the national rules in the Member States ought to be harmonised. A more level playing field would help undertakings to operate the internal market and aligned rules in the Member States would improve the conditions for consumers to exercise the rights they derive from the internal market. ${ }^{22}$ Reducing the divergence of legal rules would improve the chances of victims to obtain compensation. ${ }^{23}$

The second implication of underdeveloped private enforcement is that the number of claims ought to be increased to make competition law enforcement more effective. The Damages Directive uses terms such as 'effectively exercising the right to compensation' or 'full compensation' but actually avoids reference to expression that suggest an increase in the number of cases. Full compensation has two dimensions. It refers to the circumstance that improved legal remedies may allow the victim to recover a greater proportion of the loss suffered from anticompetitive conduct (or all of it). The White Paper's Impact Assessment clarifies what is meant by the second dimension of effective compensation: "More effective antitrust damages actions impl[y] more cases." ${ }^{24}$ It is not clear whether this refers to legal disputes in general, complaints lodged with the courts or to legal proceedings that ended with a court decisions. The number of decided cases is certainly lower than the number of settled cases but it is easier to measure. ${ }^{25}$ However, settlements are more cost-efficient and

\footnotetext{
${ }^{19}$ Commission Staff Working Paper - Annex to the Green Paper Damages Actions for Breach of the EC Antitrust Rules (Brussels 2004), para 29. See also Commission Staff Working Document - Impact Assessment Report: Damages Actions for Breach of the EU Antitrust Rules (Strassbourg 2013).

${ }^{20}$ Commission Staff Working Document - Impact Assessment (Brussels 2008), para 45.

${ }^{21}$ White Paper (n 12), para 1.1.

${ }^{22}$ Damages Directive, recital 9.

${ }^{23}$ European Commission, 'Antitrust: Commission welcomes Council adoption of Directive on antitrust damages actions' (Press release, Brussels, 10 November 2014).

${ }^{24}$ White Paper Impact Assessment (n 20), para 46; See also European Commission, 'Antitrust: Commission proposal for Directive to facilitate damages claims by victims of antitrust violations - frequently asked questions' (MEMO/14/310 of 17 April 2014).

${ }^{25}$ See for the UK experience Barry J Rodger, 'Why Not Court? A Study of follow-on Actions in the UK' (2013) 1 Journal of Antitrust Enforcement 104-131.
} 
will be preferred by the vast majority of parties over trial and court rulings. ${ }^{26}$ For the purpose of this study, I will use a wide interpretation of what is meant by effective compensation, assessing the rules of the Directive according to the incentives they provide to seek compensation in and outside the courtroom.

The assumptions that underpin the Directive and the conclusions that were drawn from it have decisively shaped the goals of the Directive. The Damages Directive pursues two aims: compensation and the coordination of public and private enforcement. Article 1(1) of the Directive sets out the first goal of the Directive: strengthening the right to compensation to ensure more effective private enforcement actions. This aim reflects the jurisprudence of the CJEU that created an EU right to damages in the seminal Courage and Manfredi decisions. ${ }^{27}$ According to the Court, every individual ought to be able to claim compensation for loss caused by the breach of EU competition rules in the courts of the Member States. Flanked by the principle of effectiveness, national rules for damages actions must not render the enforcement of the right to compensation impossible or excessively difficult.

The Directive's second goal is the coordination of public and private enforcement, Article 1(2). The European Commission states in its Impact Report that the interaction between public and private enforcement has become problematic due to private parties seeking access to documents of the competition authorities. ${ }^{28}$ Access requests create 'legal uncertainty and the risk of negative consequences on the public enforcement of EU competition law. ${ }^{29}$ The coordination function addresses concerns regarding the protection of confidential files in the hands of the competition authorities. ${ }^{30}$ In the context of the Directive, this means implementing safeguards to protect leniency and settlement submissions from access. More protection for these documents was deemed necessary after the CJEU had designed a case-by-case test for requests seeking access to leniency

\footnotetext{
${ }^{26}$ The authors of the Georgetown Study on Private Antitrust Enforcement report a settlement rate of 85 per cent. Jeffrey M Perloff and Daniel L Rubinfeld, 'Settlements in Private Antitrust Litigation' in Lawrence J White (ed), Private Antitrust Litigation: New Evidence, New Learning (MIT Press, Cambridge Mass. 1988) 149, 163.

${ }^{27}$ Courage (n 10); Manfredi (n 10).

${ }^{28}$ Impact Report (n 19).

${ }^{29}$ Impact Report (n 19), para 34.

${ }^{30}$ See Recital 6.
} 
material. ${ }^{31}$ It should be borne in mind that this 'interaction' problem occurs in follow-on litigation. Follow-on cases are typically brought after a competition authority has adopted an infringement decision. The claimants normally intend to rely on information contained in the confidential or public version of the decision to benefit from the evidentiary value thereof. $^{32}$

This brief survey of the Directive's history documents the chequered formation and the main goals of the Directive. The conflict between the two main goals is obvious: while the Directive is supposed to facilitate compensation it also attempts to safeguard public enforcement when there is a risk of conflict between private and public enforcement. The tensions between the objectives are reflected in the rules of the Directive which I am going to describe in the next section.

\section{Outline of the Damages Directive}

This subsection provides a short summary of the various rules contained in the Directive. This overview is needed to facilitate the assessment in part C. The Directive is mainly going to affect three areas of private antitrust litigation: Access to evidence, liability of multiple defendants, and the role of indirect purchasers (standing of indirect purchasers and passingon defence).

The Directive facilitates access to evidence via disclosure in those jurisdictions that do not allow for the disclosure of documents in civil proceedings. Articles 5 requires the disclosure of documents in national proceedings from the opposing party or any third party subject to a reasoned request and court control. The national court must use a proportionality test to weigh the interests in favour of and against disclosure. The court should consider the supporting material that underpins the access request, the scope and cost of disclosure, and

\footnotetext{
${ }^{31}$ Case C-360/09 Pfleiderer AG v Bundeskartellamt, ECLI:EU:C:2011:389 [2011] ECR I-05161; Case C-536/11 Bundeswettbewerbsbehörde v Donau Chemie AG, ECLI:EU:C:2013:366, not yet reported.

${ }^{32} \mathrm{My}$ definition of follow-on litigation includes cases that are brought parallel to a public investigation. These parallel cases are normally brought because the on-going public investigation has signalled a potential breach of competition law.
} 
whether the evidence that is to be disclosed contains confidential information. ${ }^{33}$ The Directive incorporates the recent jurisprudence of the CJEU, allowing claimants to specify categories of documents to facilitate the disclosure procedure. ${ }^{34}$

Disclosure is restricted for material that is or was in the hands of a competition authority. ${ }^{35}$ Those requests normally occur in follow-on actions, i.e. damages claims that are initiated parallel to or after a public investigation by a competition authority. Requests for access to documents held by competition authorities are subject to a much stricter proportionality test, Article 6(4). Article 6(6) 'blacklists' leniency and settlement submissions. These documents enjoy 'absolute' protection from disclosure and cannot be revealed to accessseeking parties at any time. Article 6(5) establishes a temporary blacklist. This closed category includes: (i) information that was specifically prepared for the proceedings of a competition authority; (ii) information the competition authority has drawn up and sent to the parties; and (iii) withdrawn settlement submissions. This material is protected from disclosure requests until the competition authority has adopted a decision or otherwise terminated the proceedings.

The second area of reform relates to the liability of multiple defendants, typically a problem in cartel cases. Article 11(1) holds co-infringers jointly and severally liable. Any defendant is potentially liable for the whole amount of the damage caused by all co-infringing firms to a particular claimant. The potential claimant is given a choice to sue one, some, or all infringers for the total amount of the loss that he has suffered from a joint infringement. The flipside of joint and several liability is that the defendants have to sort out their respective shares of the overall harm among themselves. The Directive creates a number of exceptions from the rule of joint and several liability. Small- or medium-sized companies are liable only for the damage done to their direct and indirect purchasers, Article 11(2). This exception applies if the firm has a market share of less than 5 per cent and if "[...] the application of the normal rules of joint and several liability would irretrievably jeopardize [the small or medium-sized company's] economic viability and cause its assets to lose all

\footnotetext{
${ }^{33}$ Article 5(3).

34 Donau Chemie (n 31) and Case C-365/12 P Commission v EnBW Energie Baden-Württemberg AG, ECLI:EU:C:2014:112. The latter case deals with access to documents according to Regulation 1049/2001.

${ }^{35}$ For a detailed analysis of access to information see Sebastian Peyer, 'Access to Competition Authorities' Files in Private Antitrust Litigation' (2015) 3 Journal of Antitrust Enforcement 58-86.
} 
their value". ${ }^{36}$ Ringleaders, repeat offenders or firms that have coerced others into participating in the illegal conduct cannot benefit from this exception. Joint and several liability is further restricted in instances where the defendant has received full immunity from fines for cooperating with a competition authority, Article 11(4). The immunity recipients will be liable for the harm caused to its direct and indirect purchasers. If claimants are not able to receive full compensation from the other co-infringers, they may fall back on the immunity recipient.

Settling defendants will benefit from an exemption of joint and several liability and limitations regarding the contribution between joint infringers, Article 19. If the claimant settles, his damages claim is reduced by the full amount of the defendants' share in the claimant's overall loss. It is irrelevant whether or not the claimant received a settlement payment covering the full amount of the loss caused by the settling infringer. ${ }^{37}$ This rule can be best clarified with an example. Assume that the claimant has suffered a total loss of $£ 100$. The settling defendant has caused $£ 50$ of the claimant's total harm. The claimant and the defendant settle for $£ 25$. According to Article 19(1), the remaining claim of the plaintiff is reduced by $f 50$ (the share) rather than $£ 25$ (the actual settlement reward). In other words, the claimant can only recover a residual of $f 50$ from the non-settling infringers. By the same token, the settling defendant is protected from further contribution claims. The non-settling defendants cannot ask the settling defendant for contribution with regards to the remaining claim, Article 19(2). In our example, the settling defendant does not owe contribution for any payments the other defendants make towards the claimant's remaining loss of $£ 50$. It is apparent that the rule in Article 19 may lead to compensation payments that are below the actual loss the claimant has suffered. To address this issue the Damages Directive revives the settling defendant's liability if the claimant is unable to obtain full compensation from the non-settling co-infringers. The liability for any remaining and uncompensated loss is not renewed when it is expressly excluded in the settlement agreement. This is likely to be the default option for settling defendants.

\footnotetext{
${ }^{36}$ Article 11(2)(b) of the Directive. According to Commission Recommendation of 2003/361/EC of 6 May 2003 a small or medium-sized firm has less than 250 employees and a maximum annual turnover of $€ 50$ million.

${ }^{37}$ Recital 51.
} 
The third area of reform in the Directive is the standing for direct and indirect purchasers and the related passing-on defence. Article 12 grants both direct and indirect purchasers the right to sue for damages. If, for example, wholesalers and retailers have suffered harm from an upstream cartel of manufacturers, both have standing to bring a case for the loss they have suffered. To help indirect purchasers to prove standing, Article 14(2) creates a rebuttable presumption that harm was passed on to indirect purchasers if: (a) the defendant has committed an infringement; (b) the infringement resulted in an overcharge for the direct purchaser; and (c) the claimant shows that he has purchased affected goods or services. The defending company is allowed to invoke the passing-one defence but it bears the burden of proof, Article 13. With a passing-on defence, the defendant asserts that the direct purchaser did not suffer any loss or loss that is less than the overcharge because the direct purchaser was able to transfer it to the indirect purchaser. To facilitate the defendant's burden of proof, the Damages Directive stresses that the defendant may request reasonable disclosure from the claimant, Articles 13 and 14(1).

In addition to these three larger areas of reform, the Directive includes some additional measures to facilitate damages actions. Article 9 declares the final infringement decision of the EU Commission or a national competition authority binding. The binding effect precludes a national court from adopting decisions in private litigation that would run counter to the authority's final decision on which the claimant's rely. The binding effect is limited to national decisions in the respective jurisdiction and decisions of the European Commission but foreign decisions are given the status of prima facie evidence, Article 9(2). Article 10 sets a minimum limitation period for damages claims of no less than five years starting to run from the time the infringement has ceased and the claimant knows or should reasonably have known about the infringement. The limitation period applies to both standalone and follow-on actions. However, follow-on actions benefit from a suspension of the period of limitations for the duration of the public investigation, Article 10(4). To encourage out-of-court settlements, the Directive orders the suspension of the period of limitations for the period of consensual dispute resolution, Article 18(1). Courts can estimate the harm caused by competition law infringements where the available evidence does not permit a precise quantification of damages, Articles 12(5) and 17(1). Article 17(2) creates a presumption that a cartel infringement has caused harm. 
This brief summary of the main rules of the Damages Directive shows that some of the pressing issues in antitrust litigation have not been addressed, namely cost rules and claim aggregation. The European Commission has recommended that Member States adopt optin class actions but this is not a binding legal measure. ${ }^{38}$ The Directive does not deal with claim funding arrangements, the costs of bringing a private action or the costs that are associated with proving damages. The question is whether the selective legal measure are able to achieve the goal of more effective compensation. In the next section, I will look at the factors that influence a claimant's decision to sue more generally. That section is followed by a more in-depth review of the potential effects of the Damages Directive on the incentives to seek redress.

\section{Analytical framework}

The Damages Directive aims at more effective compensation by introducing measures that are to increase the willing of victims to seek redress for the breach of competition law. ${ }^{39}$ The question is which factors motivate claimants to commence action against a firm that has allegedly breached competition law and, subsequently, lead to greater enforcement activity and more effective compensation. ${ }^{40}$ Economists have studied the mechanisms of legal disputes from both theoretical and empirical perspectives. In this section, I will outline a simple framework to analyse the incentives of harmed individuals to engage in settlement negotiations and legal disputes. This helps to assess the measures that are included in the Damages Directive. It may also prove useful in answering the question as to whether those measures are likely to increase the willingness to commence legal action and, consequently, are likely to increase the number of antitrust damages claims or the amount of damages

\footnotetext{
${ }^{38}$ Recommendation (n 18).

${ }^{39}$ See section B.I.

${ }^{40} \mathrm{An}$ increase in the number of damages claims is a sign for relatively more enforcement actions if we hold the number of breaches constant. It is theoretically possible that legal measures lead to an increase in the number of violations and, assuming a fixed rate of detection, to more enforcement actions. This would be the opposite of what the Directive aims to achieve. Consequently, the number of cases is not a good indicator for the effectiveness of private enforcement, Steven C Salop and Lawrence J White, 'Economic Analysis of Private Antitrust Litigation' (1986) 74 Georgetown Law Journal 1001-1064.
} 
received. ${ }^{41}$ Since the Directive focuses on compensation, I will not consider models that look at optimal deterrence. The insights gained in this part of the paper will be applied to the rules of the Directive in section $D$.

The rational claimant's decision to initiate legal actions will normally be based on a costbenefit analysis. ${ }^{42}$ A prospective claimant will sue if he is to expect a positive payoff, typically a monetary award..$^{43}$ In the context of competition damages litigation, it means that the claimant is more likely to sue if he expects to obtain a damages or a settlement payment that outweighs the costs of initiating legal action. The decision of the claimant can be formalised, using a simple model proposed by Renda et al. ${ }^{44}$ This model will help to assess the legal rules of the Directive in the next section. ${ }^{45}$

Assume that an individual suffers a loss from the breach of competition law. Any legal response to obtain compensation is costly. The harmed individual would need to pay, for example, solicitors, court fees and expert witnesses. These costs can be divided into the costs for negotiating a settlement $\left(C_{s}\right)$ the costs for trial that are recoverable under the loser pays rule $\left(C_{t}\right)$ and the costs for trial expenses that are not recoverable $\left(C_{f}\right) .{ }^{46} C_{s}$ and $C_{f}$ include opportunity costs, for example, the cost of the time that is devoted to the dispute

\footnotetext{
${ }^{41}$ For an overview about factors influencing litigation, see Morten Hviid and John Peysner, 'Comparing Economic Incentives across EU Member States' in Barry J Rodger (ed), Competition Law: Comparative Private Enforcement and Collective Redress across the EU (Kluwer Law International, Alphen aan den Rijn 2014$) 195$.

42 William M Landes, 'An Economic Analysis of the Courts' (1971) 14 Journal of Law \& Economics 61-107; Richard A Posner, 'An Economic Approach to Legal Procedure and Judicial Administration' (1973) 2 Journal of Legal Studies 399-458; Steven Shavell, 'Suit, Settlement, and Trial: A Theoretical Analysis Under Alternative Methods for the Allocation of Legal Costs' (1982) 11 Journal of Legal Studies 55-82.

43 Ilya Segal and Michael Whinston, 'Public vs Private Enforcement of Antitrust Law: A Survey' (2007) 28 European Competition Law Review 306-315, 311.

${ }^{44}$ See Renda (n 14), 175.

${ }^{45}$ The basic model was developed and refined by Landes ( $\mathrm{n} 42$ ); Posner ( $\mathrm{n} 42$ ); John P Gould, 'The Economics of Legal Conflicts' (1973) 2 Journal of Legal Studies 279-300; Lucian A Bebchuk, 'Litigation and Settlement Under Imperfect Information' (1984) 15 RAND Journal of Economics 404-415. See also Robert D Cooter and Daniel L Rubinfeld, 'Economic Analysis of Legal Disputes and Their Resolution' (1989) 27 Journal of Economic Literature 1067-1097. For models with a focus on antitrust litigation see Perloff and Rubinfeld (n 26); George J Benston, 'A Comprehensive Analysis of the Determinants of Private Antitrust Litigation, with Particular Emphasis on Class Action Suits and the Rule of Joint and Several Damages' in Lawrence J White (ed), Private Antitrust Litigation: New Evidence, New Learning (MIT Press, Cambridge Mass. 1988) 271; Sylvain Bourjade, Patrick Rey and Paul Seabright, 'Private Antitrust Enforcement in the Presence of Pre-trial Bargaining' (2009) 57 Journal of Industrial Economics 372-409.

${ }^{46}$ In the English system only reasonable or proportionate costs are recoverable.
} 
rather than to something else. Any party initiating steps to obtain monetary redress expects a reward, typically a monetary payment from either settlement (S) or trial (D). The dispute will settle with probability $(p)$. If the case does not settle with probability (1-p), the claimant has a probability of winning (w) at trial. An injured party will initiate legal proceedings if the expected value from settlement and litigation is greater than zero: ${ }^{47}$

\section{[Insert equation (1) here]}

It is important to note that the individual's decision depends on the perception of the probability to obtain a settlement $(p)$, the probability to win at trial $(w)$, the reward after trial (D), the reward after settlement (S) and legal cost $\left(C_{s}, C_{t}\right.$ and $\left.C_{f}\right)$. In the real world, the potential claimant does not know how long settlement negotiations are going to last or what the final settlement payoff is going to be. This uncertainty is likely to lead to errors regarding the estimation of these factors. If the parties have very different expectations about the potential outcome of the legal dispute, their threat values are unlikely to meet, preventing successful pre-trial bargaining. The claimant may be overly optimistic as to the probability of winning at trial or he overestimates the potential reward from litigation. He may overestimate the value of litigation and settlement and, thus, reduce the chances that the defendant's offer meets his expectations. ${ }^{48}$ The idea underpinning the model is that private claimants aim to maximise profits; i.e. the perceived gains from legal action provide the incentives for victims to enforce the law.

As I have outlined above, it is important to look at the incentives to settle a dispute in order to assess whether a legal framework such as the Damages Directive will lead to more effective compensation. ${ }^{49}$ The costs of settlement $\left(C_{s}\right)$ are expected to be lower than the costs of going to court $\left(C_{t}\right.$ and $\left.C_{f}\right)$. The reward from settlement $(S)$ is presumed to be smaller than the reward from litigation (D). Although settlement payments are usually lower than the harm that has actually accrued, rational parties will settle as it reduces litigation cost

\footnotetext{
${ }^{47} \mathrm{I}$ am indebted to Morten Hviid and Cosmo Graham for their helpful suggestions.

${ }^{48}$ Cooter and Rubinfeld ( $\mathrm{n} 45$ ).

${ }^{49}$ See section B.I. above.
} 
and removes the uncertainty of court proceedings. ${ }^{50}$ Empirical evidence suggests that only a small fraction of disputes is actually decided by a judge or reaches the trial stage. ${ }^{51}$ Thus, the question is whether a given rule change affects the bargaining position of the parties at the settlement stage as well as their position when arguing the case in the courtroom. ${ }^{52}$ Ideally, legal rules reduce the divergence between the parties' perception to win and, thus, encourage settlement by, for example, improving access to information. ${ }^{53}$

It is difficult to predict exactly how the change of a single rule will affect the incentives of claimants or how it will operate in a given legal system. ${ }^{54}$ However, some general observations can be made. Rules that reduce the costs of the claimant $\left(C\right.$, including $C_{s}, C_{t}$ and $\mathrm{C}_{\mathrm{f}}$ ), encourage injured parties to use judicial tools to resolve their disputes. ${ }^{55}$ Similarly, a higher potential reward, i.e. increasing D or S, will induce the injured party to commence legal proceedings. Cost efficiencies could be realised by making evidence more easily available or by allowing for the aggregation of multiple individual claims. The injured individual is "[...] more likely to sue when his perceived probability of success is greater, when his litigation costs are lower, and when his rewards from success are greater." ${ }^{56}$ Legal measures and policies are likely to influence the decision to seek redress because the can either reduce or increase the perceived value of probability of success, expected rewards and expected costs. In the following section, I will look at the rules of the Directive in an attempt to determine whether those rules are likely to contribute to effective compensation by providing incentives for injured parties to seek redress.

\footnotetext{
50 ibid.; Jeffrey M Perloff, Daniel L Rubinfeld and Paul Ruud, 'Antitrust Settlements and Trial Outcomes' (1996) 78 The Review of Economics and Statistics 401-409; Perloff, Rubinfeld and Ruud (n 50).

${ }^{51}$ Perloff and Rubinfeld (n 26). report that 85 per cent of antitrust cases in their sample settled. See also George L Priest and Benjamin Klein, 'The Selection of Disputes for Litigation' (1984) 13 Journal of Legal Studies 1-55.

52 Gary M Fournier and Thomas W Zuehlke, 'Litigation and Settlement: An Empirical Approach' (1989) 71 The Review of Economics and Statistics 189-195.

${ }^{53}$ See section D.I. below.

${ }^{54}$ Avery W Katz, 'Indemnity of Legal Fees' in Gerrit d Geest and Boudewijn Bouckaert (eds), Encyclopedia of Law and Economics: Volume I - The History and Methodology of Law and Economics (Edward Elgar Publishing, Cheltenham 2000) 63.

${ }^{55}$ Bourjade, Rey and Seabright (n 45).

${ }^{56}$ Salop and White (n 40), 1019.
} 


\section{Incentives to seek compensation and the Damages Directive}

In the previous section, I outlined a simple model of the settlement and litigation process. It helped to clarify that the willingness to seek redress depends on the expected probability to settle or win in court ( $p$ and $w$ ), the expected size of the reward after settlement (S) or trial (D), and the expected costs (C). In this section, I will look at how the rules in the Directive potentially affect the incentives to initiate legal action.

\section{Access to evidence}

The Directive introduces disclosure to facilitate access to evidence in competition damages cases in many Member States. ${ }^{57}$ Disclosure forces the other party in a legal dispute to reveal information. It addresses two problems: It remedies information asymmetries between the parties when, for example, the infringer has better information about the actual harm caused to the victim. ${ }^{58}$ Information revelation can also decrease uncertainty as to the expected probability to win or the expected payoff from legal action. It will usually improve the quality of the information held by both parties, helping the parties to better estimate the value of the reward from settlement (S) or litigation (D). Especially in follow-on cases, where information is already available, the disclosure of documents may not always have a positive or negative influence on the probability to win, but it reduces the error with which the probability is estimated. This is important for settlement negotiations. Parties settle if they receive a surplus from settling compared to the non-cooperative (trial) strategy. ${ }^{59}$ But settlement will only occur if the expectations are aligned, i.e. one party's threat value is met by the other party's settlement offer. ${ }^{60}$ With better access to information the threat values

\footnotetext{
${ }^{57}$ Some EU jurisdictions, notably the UK, have mandatory disclosure regimes.

${ }^{58}$ Bruce L Hay, 'Civil Discovery: Its Effects and Optimal Scope' (1994) 23 Journal of Legal Studies 481-515.

${ }^{59}$ Robert B Cooter, Law and Economics (6th ed. Pearson, Boston 2014), 60.

${ }^{60}$ The threat value is the claimant's minimum value for which he would be willing to settle or the maximum value for which the defendant would accept a settlement. The claimant's expected gain from trial is represented by $w_{p} D-\left(1-w_{p}\right) C_{t}-C_{f}$ where $\mathrm{w}_{\mathrm{p}}$ is the claimant's probability to win. The defendant's
} 
are likely to become more realistic and, thus, the likelihood of settlement and compensation payments increases.

As for the problem of information asymmetry, it is claimed that incriminating evidence is frequently in the hand of the defendant who, without mandatory disclosure, is unlikely to reveal harmful information. ${ }^{61}$ Any party to a dispute is normally willing to voluntarily disclose information that has a negative value to its opponent because such information reduces the other side's expected award (S or D) or the probability to win $(w) .{ }^{62}$ If, for example, the defendant has information showing that the claimant has no case or lost less than averred, the defendant will reveal the material to reduce the claimant's expected damages award and chances of winning. At the same time, parties to a legal dispute are more likely to withhold information when it may prove harmful to their own case. Mandatory disclosure, as arranged for in the Directive, overcomes the problem of information being withheld. It is particularly useful in antitrust disputes where a defending monopolist or cartel member is likely to have better information about the infringement and the overcharge.

By allowing disclosure the drafters of the Damages Directive hope to incentivise victims to file more damages claims in the courts and to improve the probability that victims receive full compensation. ${ }^{63}$ Better information improves the accuracy of judges' decision making and facilitates the calculation of the actual loss. Whether or not disclosure increases the number of court decisions depends on the information parties are likely to obtain from their respective opponents and whether parties have been relatively optimistic or pessimistic regarding their chances of success. A relatively optimistic claimant has relatively greater expectations of winning, i.e. he is likely to overestimate the expected value from bringing a damages claim. If the defendant has an equally optimistic expectation of successfully defending against that claim, the parties are less likely to settle. If both parties are relatively pessimistic about their chances to win, i.e. the claimant values his chances of winning as

\footnotetext{
threat value (expected loss) is $-w_{d}\left(D+C_{t}\right)+\left(1-w_{d}\right) C_{t}-C_{f}$ with $\mathrm{w}_{\mathrm{d}}$ being the defendant's probability to successfully defend. The latter expression represents the maximum the defendant would be willing to offer to the claimant.

${ }^{61}$ Recital 14.

${ }^{62}$ Cooter and Rubinfeld ( $\mathrm{n} 45$ ).

${ }^{63}$ Recital 15.
} 
being relatively low and the defendant rates his chances of successfully defending against the claim as low too, a settled outcome is more realistic. ${ }^{64}$ Mandatory disclosure can either increase or decrease optimism, depending on the evidence that is being found. Thus, theory is unable to predict whether or not more cases will be decided by the courts. ${ }^{65}$ It is more likely that disclosure will reveal incriminating evidence in follow-on cases where an infringement has already been established by the competition authority. More generally, altering the rules on evidence, including disclosure, affects the probability that a claimant will win at trial. ${ }^{66}$ This, in turn, can affect the probability with which parties settle their disputes. $^{67}$

The disclosure rules in the Directive possibly encourage victims to seek compensation from the wrongdoer, especially in follow-on cases in which the claimants rely on a decision of the competition authorities. In those cases victims can be certain that the defendant possesses incriminating material. Better access to information can improve the claimant's valuation of the chances to succeed (w) and the valuation of the actual loss (S or D). The rules on disclosure are likely to have a positive effect on the incentives to bring a claim in those jurisdictions where disclosure does not exist. ${ }^{68}$ The threat of disclosure is also more likely to lead to an increased settlement rate which helps to save resources, provided that none of the parties is relatively optimistic. The question is whether these potential benefits are outweighed by the costs of disclosure. ${ }^{69}$

Disclosure raises questions as to the scope of disclosure, i.e. how much and what kind of information should be revealed. ${ }^{70}$ This question is closely related to the costs of information revelation which, as the US experience shows, are substantial. ${ }^{71}$ The more documents are to be disclosed, the greater the costs of providing and analysing the information. The Directive

\footnotetext{
${ }^{64}$ Perloff, Rubinfeld and Ruud (n 50).

65 Cooter and Rubinfeld ( $\mathrm{n} 45$ ); Robert D Cooter and Daniel L Rubinfeld, 'An Economic Model of Legal Discovery' (1994) 23 Journal of Legal Studies 435, 448.

${ }^{66}$ Perloff, Rubinfeld and Ruud (n 50).

67 Henry S Farber and Michelle J White, 'Medical Malpractice: An Empirical Examination of the Litigation Process' (1991) 22 RAND Journal of Economics 199.

${ }^{68}$ The effects in England and Wales, where disclosure already exists, may be different.

${ }^{69}$ For the potential abuse of disclosure see Cooter and Rubinfeld ( $\mathrm{n} 65$ ).

${ }^{70}$ Hay (n 58).

${ }^{71}$ Scott A Moss, 'Litigation Discovery Cannot be Optimal but Could be Better: the Economics of Improving Discovery Timing in a Digital Age' (2009) 58 Duke Law Journal 889.
} 
tries to strike a balance between achieving better access to information and cost savings, suggesting a proportionality test that balances benefits and costs. This is a more general attempt to keep the costs of disclosure at bay. However, the Damages Directive does not regulate which party bears the financial burden of disclosure. The financial burden of disclosure is a crucial issue because depending on who pays those expenses it can encourage legal action and settlements.

It has been pointed out that the cost rules regarding discovery may lead to asymmetric cost distribution and, thus, influence bargaining and settlement. ${ }^{72}$ In other words, the threat of the costs associated with disclosure could encourage the innocent defendant to settle prior to the exchange of information in order to avoid these costs. An active judicial control of disclosure and costs may reduce the risk that the defendant is 'blackmailed' into a settlement. For example, parties in the English courts are only obliged to conduct a 'reasonable search' for documents when giving standard disclosure, allowing them to limit the categories of documents that are being searched. ${ }^{73}$ Similarly, the prospect of cost management and cost capping may reduce the influence of potential disclosure costs on the innocent defendant's decision. ${ }^{74}$

Even with measures to control costs in place, the question of who is going to bear the costs of disclosure has a considerable effect on the incentives to commence legal action. ${ }^{75}$ If disclosure expenses fall under potentially recoverable legal costs like, for example, in England and Wales, the losing party may have to pay some or all of the costs incurred as part of the reasonable costs. ${ }^{76}$ Applying the English rule to the model above, the costs of disclosure would fall under $C_{t}$ and the non-recoverable portion under $C_{f}$. Thus, the greater the non-recoverable part of the costs, the lower will be the expected award from litigation.

\footnotetext{
72 Perloff, Rubinfeld and Ruud (n 50); Frank H Easterbrook, 'Discovery as Abuse' (1989) 69 Boston University Law Review 635-648.

${ }^{73}$ Civil Procedure Rules 31.7(1)-(3).

${ }^{74} \mathrm{See}$, for example, the first cost-capping decision of the UK's Competition Appeal Tribunal in Socrates Training Limited $v$ The Law Society of England and Wales [2016] CAT 10. The court may also disallow all or part of the costs, Civil Procedure Rules 44.11.

${ }^{75}$ William H Wagener, 'Modeling the Effect of One-way Fee Shifting on Discovery Abuse in Private Antitrust Litigation' (2003) 78 New York University Law Review 1887-1928.

${ }^{76}$ Civil Procedure Rules 44.1 to 44.5 . The principle of reasonableness/proportionality can severely limit the recoverable costs, see, for example, Tesco Plc v Competition Commission [2009] CAT 26 (applying rule 55 of the Competition Appeal Tribunal Rules 2003).
} 
This, in turn, reduces the expected award from settlement negotiations. Unless the claimant's subjective expectation of winning is high, this may reduce the incentives to seek compensation.

Member States could also adopt a rule according to which each party bears its own costs of disclosure, similarly to the cost rules in the United States. Such a rule would potentially provide more incentives to sue as it lowers the costs of legal action for a claimant that possesses little valuable information like, for example, a consumer in a cartel case. The costs of disclosure for such a claimant would consequently be relatively low. It is surprising that the costs of disclosure are not regulated in the Damages Directive, given that disclosure costs exert a considerable impact on the incentives to sue. Member States are free to choose whether disclosure costs are born by the disclosing party, or fully or partly recoverable by the winning party. National disclosure rules may offer varying incentives for claimants and, thus, Member States may use cost rules to attract or discourage legal actions in their respective jurisdiction.

\section{Joint and several liability}

Joint and several liability and the rules governing contribution also have an effect on the willingness of defendants to settle and, thus, on the compensation that is potentially paid to victims of anticompetitive conduct. ${ }^{77}$

In a system of joint and several liability, the claimant can choose whether to sue one, some or all of the defendants if the infringement was committed jointly. This choice increases the chance that the claimant will fully recover his loss if one of the tortfeasors is unable to pay damages or part thereof. Many EU jurisdictions provide for joint and several liability. The general rule is that one infringer is liable for the entire harm caused by all tortfeasors but national rules may allocate the harm differently based, for example, on the degree of

\footnotetext{
${ }^{77}$ For a detailed discussion of different contribution rules see Timothy J Stanley, 'An Analysis of the Rules of Contribution and no Contribution for Joint and Several Liability in Conspiracy Cases' (1994) 35 Santa Clara Law Review 1-122.
} 
culpability. ${ }^{78}$ The rules of the Directive change three aspects: First, they remove small and medium-sized firms from the pool of jointly liable defendants if certain criteria are satisfied. ${ }^{79}$ Second, they create uncertainty as to the liability of the immunity recipient and they obfuscate the incentives of firms to settle disputes. Thirdly, they limit the overall amount of compensation that can be obtained from jointly and severally liable defendants if the claimant settles with one of them.

Most economic models of joint and several liability look at the effects on the defendants' incentives to settle rather than on the claimants' incentives to sue. ${ }^{80} \mathrm{~A}$ higher proportion of settled disputes reduces litigation costs but it does not answer the question which rule proportionate or joint and several liability - provides greater incentives to seek compensation. The predictions as to the effects of joint and several liability and the contribution rules differ. Some economists find that claimants are able to extract more damages in a system of joint and several liability but that such a system leads to a lower rate of settlements. ${ }^{81}$ Others demonstrate that joint and several liability leads to higher levels of aggregate damages and that more information is revealed to the private plaintiff if there is no contribution between the defendants. ${ }^{82}$ In the simple litigation model I outlined above, a higher damages award would increase the expected value from litigation (D) or settlement (S) and encourage victims to commence legal action. If a joint and severally liable defendant settles early and provides information to the claimant, this may increase the probability of winning $(w)$ or successfully settling $(p)$ subsequent disputes against the remaining infringers.

\footnotetext{
${ }^{78}$ Recital 37.

${ }^{79}$ See section B.Il. above.

${ }^{80}$ Frank H Easterbrook, William M Landes and Richard A Posner, 'Contribution among Antitrust Defendants: A Legal and Economic Analysis' (1980) Journal of Law and Economics 331; A. M Polinsky and Steven Shavell, 'Contribution and Claim Reduction among Antitrust Defendants: An Economic Analysis' (1981) 33 Stanford Law Review 447; John Cirace, 'A Game Theoretic Analysis of Contribution and Claim Reduction in Antitrust Treble Damage Suits' (1980) 42 St. John's Law Review 42-62; Lewis A Kornhauser and Richard L Revesz, 'Multidefendant Settlements: The Impact of Joint and Several Liability' (1994) 23 Journal of Legal Studies 41; Howard F Chang and Hilary Sigman, 'Incentives to Settle Under Joint and Several Liability: An Empirical Analysis of Superfund Litigation' (2000) 29 Journal of Legal Studies 205.

${ }^{81}$ Nicholas Dopuch, Daniel E Ingberman and Ronald R King, 'An Experimental Investigation of Multi-defendant Bargaining in 'Joint and Several' and Proportionate Liability Regimes' (1997) 23 Journal of Accounting and Economics 189-221.

82 Morten Hviid and Andrei Medvedev, 'The Role of Contribution among Defendants in Private Antitrust Litigation' (2010) 30 International Review of Law \& Economics 306-316.
} 
The potential effects of the Damages Directive's rules of joint and several liability on the incentives to sue are ambiguous. The complicated system of exemptions in the Directive makes it difficult to predict whether injured parties will be encouraged to seek redress. Complex legal rules may have benefits, ${ }^{83}$ but they are likely to raise expected litigation costs. Potential claimants are unlikely to know at the outset whether the exemption for small and medium-sized companies applies to the defendant. This has to be established in court; it normally requires more evidence and creates uncertainty as to the outcome of the trial. The exemptions also increase uncertainty as to reward the claimant can expected after all proceedings have been closed. It is possible that reducing the number of liable codefendants via exemptions reduces the expected reward from damages litigation or increases the risks and potential length of the proceedings.

The arrangements for settling defendants are particularly puzzling and may create unintended incentives on part of the claimant. According to Article 19(1) of the Directive, settlements will reduce the claimants' remaining claim against other infringers by the whole share of harm that the settling defendant has caused to the claimant. ${ }^{84}$ In our example from above, the claimant settled for 25 although the settling infringers share was 50 . The overall claim was 100 but is reduced by the share of 50 and not by the actual amount paid. ${ }^{85}$ This would give a claimant an incentive to obtain settlements from those infringers that have not caused direct harm to him but are jointly and severally liable. Settling with infringers from which the claimant did not purchase would reduce the claim only by the settled amount rather than the settling defendant's share because the latter is zero in the absence of direct dealings. Alternatively, one could argue that the claim is not reduced at all when settling with a jointly and severally liable infringer that did not have direct dealings with the claimant. Article 19(1) reduces the settling injured party's claim by the share of the harm inflicted upon the injured party which, in this instance, would be zero. This must be a mistake as it could potentially lead to overcompensation, something the drafters of the Directive sought to exclude with Article 3(3).

\footnotetext{
83 Louis Kaplow, 'A Model of the Optimal Complexity of Legal Rules' (1995) 11 Journal of Law, Economics, \& Organization 150.

${ }^{84}$ See explanation in section B.II.

${ }^{85}$ Recital 51.
} 
While the claimant may have an incentive to pursue settlement negotiations with the defendants that have not directly harmed him, it is questionable whether those 'non-direct' defendants have an incentive to settle. The infringer that did not have direct dealings with the claimant has an incentive to hold out until the claimant has settled with other infringers. Those settlements would potentially reduce the remaining claim to zero even though the claimant has not received full compensation. Because there is a risk that the claimant would forego full compensation, he has no incentive to settle first with a defendant that has caused direct harm to him if this would result in a settlement award that is lower than the harm caused by this particular defendant. Such a settlement would reduce this part of the claim to zero even if the settlement amount covers only a fraction of the harm that was caused by the settling infringer. The claimant cannot recover the difference between actual harm and settlement from the other co-infringers. Only if we assume that there are nonrecoverable costs $\left(C_{f}\right)$ on part of the non-direct defendant, it seems plausible for this defendant to settle if he was still better off compared to litigation or holding-up. To fully understand the complex dynamics of these exemption rules, further modelling is required. It appears though that the Directive does not align the incentives of claimants and defendants to settle. Thus, the settlement rules are likely to discourage settlements and encourage costly litigation. This may deter some claimants from asking for compensation in the first place.

In addition to the complex settlement rules, the exemption rule for the immunity recipient temporarily removes a potential defendant from the pool of joint defendants. This rules is to protect the immunity recipient from becoming a preferred target for civil claims. ${ }^{86}$ Inadvertently, the Directive may have just achieved the opposite. To avoid uncertainty as to the outcome of any other legal disputes - the immunity recipient would have to wait until the end of all other civil proceedings - he is likely to settle first, benefitting from the exclusion from any further liability under the settlement rules. The willingness of the immunity recipient to settle early could encourage injured parties to approach him in the first place and, thus, provide easier access to compensation.

\footnotetext{
${ }^{86}$ Recital 38.
} 
The incentives for claimants to bring cases against small and medium-sized enterprises as well as immunity recipient may be undermined by the unclear scope of the exemptions. The Directive reduces the liability of the immunity recipient and small companies to 'its own direct and indirect purchasers' ${ }^{87}$ The Directive does not define whether this includes harm the claimant has incurred from other defendants. Assume the potential claimant purchases affected products from several defendants. In this scenario two interpretations are possible: The victim has obtained the right to sue the immunity recipient for the whole loss caused by all defendants as long as he has bought one affected product from the immunity recipient. According to this interpretation, the claimant would be able to sue the immunity recipient for the entire cartel-related loss, including loss caused by other co-infringers. Only those who have not purchased products from the immunity recipient are barred from suing the immunity recipient in the first place. Alternatively, one could forward a narrower interpretation of the exemption that limits damages claims against the immunity recipient to the exact loss the immunity recipient has caused to its direct and indirect purchasers. Whichever interpretation Member States are going to prefer, it will reduce certainty with regards to the damages award and the probability to win.

To encourage parties to seek compensation, contribution should be based on one simple and comprehensive formula. ${ }^{88}$ The joint and several liability arrangements in the EU's antitrust damages framework are the opposite of simple. The recourse option against settling defendants is mere window dressing as no settling defendant would leave that option to a settling claimant. ${ }^{89}$ The suggested framework is complex and the standard rule is riddled with exceptions that are questionable in their scope and effect. The effects on the incentives to seek compensation are ambiguous at best.

\section{Indirect purchaser standing and passing-on defence}

\footnotetext{
${ }^{87}$ See Articles 11(2).

88 Donald I. Baker, 'Revisiting History - What Have We Learned About Private Antitrust Enforcement that We Would Recommend to Others' (2004) 16(4) Loyola Consumer Law Review 379, 388.

${ }^{89}$ See B.II.
} 
To facilitate compensation the Damages Directive grants standing to bring damages actions to indirect purchasers. ${ }^{90}$ It is argued that the expansion of standing to include indirect purchasers incorporates the Courage and Manfredi jurisprudence of the CJEU. ${ }^{91}$ The flipside of acknowledging that some or all of the harm has been passed on to the next level in the distribution chains is recognising the passing-on defence. The defendant can invoke the passing-on defence against a damages claim, asserting that the claimant has passed through some or all of the overcharge to the next level in the distribution chain. The question is how the new rules on standing for indirect purchasers and the availability of the passing-on defence affect the incentives to commence legal action, i.e. the claimant's subjective expectation regarding the award from legal action ( $D$ and $S$ ), the probability to win ( $p$ and w) and the associated costs (C).

The passing-on defence is likely to have a negative effect on the incentives of direct purchasers to bring legal actions. If the defendant can show that the claimant has shifted some or all of the overcharge to the next level in the distribution chain, the damages award of the direct purchaser is reduced by the amount that has been passed on. This has two consequences. First, it means that the expected reward from litigation or settlement (D or S) is likely to be lower compared to a framework without passing-on. ${ }^{92}$ That, in turn, reduces the incentives to sue. Second, legal costs are likely to increase. Establishing the exact amount that has been passed through to the next level is complex, adding to the costs of negotiation or litigation while, at the same, increasing the uncertainty as to the final reward from legal action. ${ }^{93}$ The quantification of the passed on overcharge requires a full analysis of

\footnotetext{
${ }^{90}$ Article 12(1), recital 41.

${ }^{91}$ Courage (n 10); Manfredi (n 10); Assimakis P Komninos, EC Private Antitrust Enforcement: Decentralised Application of EC Competition Law by National Courts (Hart, Oxford and Portland, Oregon 2008). p 203; Süleyman Parlak, 'Passing-on Defence and Indirect Purchaser Standing Should the Passing-on Defence Be Rejected Now the Indirect Purchaser Has Standing after Manfredi and the White Paper of the European Commission' (2010) 33 World Competition 31-53. Magnus Strand, 'Indirect Purchasers, Passing-on and the New Directive on Competition Law Damages' (2014) 10 European Competition Journal 361-386.

92 William M Landes and Richard A Posner, 'Should Indirect Purchasers Have Standing to Sue Under the Antitrust Laws? An Economic Analysis of the Rule of Illinois Brick' (1979) 46 University of Chicago Law Review 602-635. This is disputed by Robert G Harris and Lawrence A Sullivan, 'Passing on the Monopoly Overcharge: A Comprehensive Policy Analysis' (1979) 128 University of Pennsylvania Law Review 269-360.

${ }^{93}$ For an overview see George Kosicki and Miles B Cahill, 'Economics of Cost Pass Through and Damages in Indirect Purchaser Antitrust Cases' (2006) 51 Antitrust Bulletin 599-630.
} 
the affected markets and depends, inter alia, on the price elasticity in the downstream market. $^{94}$

The Directive allows indirect purchasers to bring damages actions against infringers that are further up the distribution chain. The typical indirect purchaser suffers a small individual loss and is often the final purchaser of the affected product; but indirect purchasers may also operate on the wholesale level. ${ }^{95}$ Indirect purchasers are remote from the actual infringement and possess little information about the nature and extent of the harm; this means that they have greater costs of searching and obtaining information. ${ }^{96}$ Many indirect purchasers are consumers who are disinclined to take large corporations to court. The available empirical evidence shows that indirect purchaser actions are a rather rare. ${ }^{97}$ For most indirect purchasers, the relatively low individual losses and, thus, potential reward (D or S) compare unfavourably to the potential costs of legal actions. Consequently, the expected value of legal action is likely to be negative and will discourage indirect purchasers from seeking damages. ${ }^{98}$

The drafters of the Directive take into account that indirect purchasers will find it difficult to obtain sufficient evidence for their claims. The rebuttable presumption that harm was passed on to indirect purchasers, Article 14(2), is meant to facilitate the proof of standing. It certainly helps the claimant to show that he is qualified to bring a claim but it does not alleviate the burden on the indirect purchaser to show exactly how much of the overcharge was passed on to him. Indirect purchasers can ask for reasonable disclosure of documents from the defendant or third parties but this will add to the overall legal costs $\left(C_{t}\right.$ and $\left.C_{f}\right)$. $A$ meaningful way to address the issue of small losses and high legal costs is to arrange for an

\footnotetext{
94 ibid. William M Landes and Richard A Posner, 'The Economics of Passing on: A Reply to Harris and Sullivan' (1980) 128 University of Pennsylvania Law Review 1274; Guidance (n 17), para 168.

${ }^{95}$ See the recent decision of the High Court of Justice in Ilyama Benelux BV \& ors v Schott AG \& ors [2016] EWHC 1207 (Ch).

${ }^{96}$ Landes and Posner (n 92), 607.

97 Robert H Lande and Joshua P Davis, 'Benefits From Private Antitrust Enforcement: An Analysis of Forty Cases' (2008) 42 U.S.F.L.Rev. 879-918; Peyer (n 7); Barry J Rodger (ed), Competition Law: Comparative Private Enforcement and Collective Redress across the EU (Kluwer Law International, Alphen aan den Rijn 2014).

${ }^{98}$ See, for example, the EU car glass cartel. Ca. 14 million cars are sold each year in the European Economic Area. Not a single indirect purchaser claims has been filed. Commission Decision Case COMP/39125 Carglass of 12 November 2008.
} 
aggregation of individual claims. The Commission has recommended an opt-in class action model but has not made this proposal binding. ${ }^{99}$ Even if all Member States introduced mechanisms to aggregate small individual losses from indirect purchasers, it is argued that the high costs of class actions outweigh the benefits thereof. If individuals with an indirect relationship with the infringer are given the right to compensation, they are likely to secure only small amounts of compensation. ${ }^{100}$

The evidence suggests that indirect purchasers do not have strong incentives to enforce the antitrust laws. Some commentators suggest that it is probably best to bar indirect purchasers from bringing cases in the interest of effective enforcement. ${ }^{101}$ Others assert that standing to both direct and indirect purchasers approximates compensation to the real harm. ${ }^{102}$ For the purpose of my analysis it is important to note that both indirect purchaser standing and the passing-on defence produce ambiguous effect on the incentives to seek compensation. Neither rule clearly encourages a group of claimants to ask for compensation. With regards to the simple litigation model, it is likely that the Directive's rules on indirect purchaser standing and the passing-on defence do not increase the expected reward (S and $D$ ) but are likely to increase the cost of legal action (C).

\section{Other rules}

To complete the analysis of the compensation objective in the Damages Directive, I will look at the remaining, probably less intrusive and least contentious rules. The Damages Directive makes decisions of the European Commission and the national competition authority binding in subsequent private proceedings. ${ }^{103}$ The statute of limitations is extended and the period of limitation stayed for violations that are investigated by a competition authority.

\footnotetext{
${ }^{99}$ Commission Recommandation (n 18).

${ }^{100}$ Landes and Posner (n 92), 609.

101 ibid. John E Lopatka and William H Page, 'Indirect Purchaser Suits and the Consumer Interest' (2003) 48 Antitrust Bulletin 531.

102 Leonardo J Basso and Thomas W Ross, 'Measuring the True Harm from Price-fixing to Both Direct and Indirect Purchasers' (2010) 58 The Journal of Industrial Economics 895-927.

${ }^{103}$ National decisions are only binding in the respective jurisdiction, Article 9.
} 
Judges are given the powers to estimate harm. I do not doubt that these rules may be useful but none of them will provide key incentives for injured individuals to seek redress.

The binding effect releases parties in follow-on disputes from proving the actual infringement. This reduces the cost of litigation $\left(C_{t}\right.$ and $\left.C_{f}\right)$ and increases the expected probability of winning in follow-on cases ( $w$ and $p$ ). The available evidence suggests that antitrust damages actions are more often than not follow-on cases, in other words, they are typically brought after the competition authority has unearthed potential evidence about wrongdoing or launched an investigation. ${ }^{104}$ Many jurisdiction have a binding effect or accept decisions of the competition authority as prima facie evidence, thus, the binding effect will not trigger a surge of new cases. Follow-on cases also depend on public investigations which are limited in numbers and, in recent years, tend to settle rather than being concluded with an infringement decision. Arguably, the follow-on rule improves legal certainty and helps parties to better estimate their chances of success. However, the Directive does not exactly define which elements of a public decision constitute the binding part. This may lead to uncertainty and, consequently, increase the potential cost of litigation, at least until this has been clarified by the courts. ${ }^{105}$ More importantly though is the fact that the quantification of harm proves to be the most expensive and timeconsuming aspect of follow-on damages claims. The binding effect does not facilitate this facet of litigation.

The new period of limitations for antitrust damages actions provides a minimum period of five years. If the national period of limitation for tort claims was shorter, the new rules gives claimants more time to bring a legal action. This rule has probably a negligible effect on the probability to win or settle or on the size of the reward from litigation.

Judges are empowered to estimate the amount of overcharge and passing-on. This is an interesting rule but, in its current shape, leaves much to be desired from a compensation point of view. It is unlikely to encourage claimants to bring legal actions. The Directive allows the estimation of harm in cases where it is 'practically impossible' or 'excessively

\footnotetext{
${ }^{104}$ Peyer (n 7); Rodger (ed) (n 97), 53.

${ }^{105}$ See, for example, the English Court of Appeal in Enron Coal Services Ltd v English Welsh \& Scottish Railway Ltd [2011] EWCA Civ 2.
} 
difficult' to 'precisely quantify the harm'. This is a rather high burden. It means that the claimant will still have to provide evidence unless he can show that he has exhausted all possible means to prove the damages - a difficult undertaking given the existence of disclosure. Just because quantification is costly does not release the claimant from this burden. Even if the judge estimates the harm, a reference point for the estimation is needed and the judge has to rely on some kind of evidence. I doubt that this rule is going to lower the claimant's burden of proof. Neither does this rule increase the reward from legal action (D), nor does it reduce the expected costs (C).

\section{E. Conclusions}

When the Damages Directive passed the Council of the European Union, it was harshly criticised by the Polish, Slovenian, and German delegations for failing its very own objectives. ${ }^{106}$ In this paper, I have demonstrated that this is certainly true for the Directive's compensation goal. Some arrangements in the Damages Directive may encourage victims to seek redress, for example, the rules regulating access to evidence may improve the probability to settle or win a damages award. They could also increase the potential award but they come at a cost that may well outweigh the benefits, especially since most EU jurisdictions feature a loser-pays principle. Most arrangements in the Directive do not contribute much to the compensation objective. The rules regarding joint and several liability do not encourage victims to seek compensation. The Directive's impetus on indirect purchaser standing and passing-on increases the costs of legal action while reducing the expected reward. Overall, the Damages Directive has a negligible impact on individuals' to seek redress in the courts, especially when the claimant is an individual consumer or does not have deep pockets to finance litigation. The Directive does not address some of the important aspects of antitrust litigation: legal costs, cost shifting and claim aggregation. It may well be that the Directive has an indirect influence on private antitrust litigation by, for

\footnotetext{
${ }^{106}$ Available at: http://data.consilium.europa.eu/doc/document/ST-14680-2014-ADD-1/en/pdf.
} 
example, changing the way infringement findings are communicated but this remains to be seen.

The Directive states that full compensation is achieved if the position of an injured individual is restored as if the infringement had not taken place. The Member States must ensure that a successful compensation claim includes redress for actual loss, loss of profits and the payment of interest. ${ }^{107}$ Given that the Directive does not encourage victims to seek compensation, it is for the Member States to put individuals in a better position to sue. This means addressing the cost issues and the problem of claim aggregation, provided the Member States agree with the underpinning assumption that more private actions mean more effective enforcement of the competition rules. Many Member States still struggle with the concept of opt-out class actions and this has opened up opportunities for Member States to compete for claims. The UK's new opt-out class action regime has yet to be tested but it appears to be a viable option to address the cost-benefit issues of victims with small individual losses. ${ }^{108}$ Redress schemes - such as, for example, those introduced in the UK could also be a solution to promote the compensation of victims. ${ }^{109}$ With regards to compensation for consumers, the courts and legislators in many Member States are already ahead of the Directive, introducing, for example, class actions. ${ }^{110}$

One could argue that the Directive is not about compensation anyway but about the protection of public enforcement in general, and leniency programmes in particular. Competition authorities assert that the release of leniency documents would undermine the incentives to blow the whistle. Cooperating firms would fear the exposure to civil claims and refrain from revealing crucial information to the competition authorities. This would mean fewer investigations and less deterrence. It would also mean fewer follow-on actions for damages. Some two thirds of cartel infringements in Europe are currently uncovered as a result of leniency, although there are some questions as to how many of those represent

\footnotetext{
${ }^{107}$ Article 3(2).

108 The first opt-out follow-on damages action was initiated in the Competition Appeal Tribunal this year, Dorothy Gibson v Pride Mobility Products Limited. The opt-out action is limited to claims brought on behalf of domiciled claimants, see section 47B(11) Competition Act as amended by the Consumer Rights Act 2015.

${ }^{109}$ See UK Consumer Rights Act 2015.

110 See, for example, Part 23a of the Danish Administration of Justice Act; Article 140 bis of the Italian Consumer Code; the Dutch class action regime under Article 3:305a BW; the UK Consumer Rights Act 2015.
} 
active and successful cartels. ${ }^{111}$ With regards to this second objective it is not clear that the Directive will lead to a better protection of public enforcement either. Immunity recipients and undertakings that settle with the competition authorities receive preferential treatment but, as I have shown above, the rules regarding joint and several liability produce ambiguous effects. Only time will show whether these rules do provide a benefit to cooperating companies. The restrictions regarding disclosure of leniency documents may help to protect leniency programmes but it remains to be seen whether this rule complies with EU law. The CJEU has emphasised that an absolute protection of leniency documents violates the right to compensation of access-seeking parties. ${ }^{112}$ The Court preferred a case-by-case approach to assess access requests. In contrast to the CJEU's position, the Damages Directive does not permit a weighing test for leniency documents and this may become the subject of a future preliminary reference.

With the Damages Directive being in force, the question is how the Member States are going to deal with it. Since the Directive does not address the most important claim-related issues, namely cost issues and claim aggregation, the Member States are free to experiment with either low-cost litigation systems or expensive class action frameworks that increase the potential reward from litigation. Either way, if more compensation is desired, the national legislators have to bear in mind that just implementing the Directive is unlikely to incentivise more victims to seek redress from firms that breached the competition rules. If private enforcement is to become a strong second pillar of competition law enforcement and some Member States show that it can complement public enforcement ${ }^{113}$ - national governments must regulate private antitrust enforcement beyond the narrow scope of the Antitrust Damages Directive.

\footnotetext{
${ }^{111}$ Andreas Stephan, "An Empirical Assessment of the European Leniency Notice" (2009) 5(3) Journal of Competition Law and Economics 537-561.

${ }_{112}$ Pfleiderer (n 31); Donau Chemie (n 31).

${ }^{113}$ Peyer (n 7).
} 


\section{Appendix}

(1)

$$
p\left(S-C_{s}\right)+(1-p)\left[w D-(1-w) C_{t}-C_{f}\right]>0
$$

